
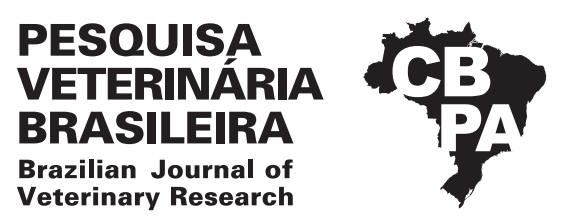

Pesq. Vet. Bras. 39(4):292-298, April 2019 DOI: $10.1590 / 1678-5150-P V B-5747$

ISSN 0100-736X (Print) ISSN 1678-5150 (Online)

\title{
Isolation, cultivation and immunofluorescence characterization of lamellar keratinocytes from equine hoof by using explants ${ }^{1}$
}

\author{
João P.H. Pfeifer'2, Vitor H. Santos², Gustavo Rosa², Jaqueline B. Souza², \\ Marcos Jun Watanabe ${ }^{2}$, Carlos E. Fonseca-Alves ${ }^{3}$, Elenice Deffune ${ }^{4}$ \\ and Ana L.G. Alves ${ }^{2 *}$ (D)
}

\begin{abstract}
Pfeifer J.P.H., Santos V.H., Rosa G., Souza J.B., Watanabe M.J., Fonseca-Alves C.E., Deffune E. \& Alves A.L.G. 2019. Isolation, cultivation and immunofluorescence characterization of lamellar keratinocytes from equine hoof by using explants. Pesquisa Veterinária Brasileira 39(4):292-298. Departamento de Cirurgia e Anestesiologia Veterinária, Faculdade de Medicina Veterinária e Zootecnia, Universidade Estadual Paulista "Julio de Mesquita Filho", Distrito de Rubião Junior s/n, Botucatu, SP 18618-681, São Paulo, Brazil. E-mail: ana.liz@unesp.br

The importance of the hoof to the horse health is clear, and the current knowledge regarding the cellular aspects of hoof keratinocytes is poor. Studies on equine keratinocyte culture are scarce. Developing keratinocyte cultures in vitro is a condition for studies on molecular biology, cell growth and differentiation. Some methods have already been established, such as those for skin keratinocyte culture. However, few methodologies are found for lamellar keratinocytes. The objective of this study was to standardize the equine hoof keratinocyte isolation and cultivation, and then characterize the cell immunophenotype. For this, the primary culture method used was through explants obtained from three regions of the equine hoof (medial dorsal, dorsal, and lateral dorsal). After the cell isolation and cultivation, the cell culture and its explants were stained with anti-pan cytokeratin (pan-CK) (AE1/AE3), vimentin (V9), p63 (4A4), and Ki-67 (MIB-1) antibodies. Cells were grown to third passage, were positive for pan-CK, p63 and Ki-67, and few cells had vimentin positive expression. As for the explants, the epidermal laminae were not stained for vimentin or Ki-67. However, some cells presented positive pan-CK and p63 expression. This study demonstrated the viability of lamellar explants of equine hooves as a form of isolating keratinocytes in primary cultures, as well as characterized the proliferation ability of such keratinocytes in monolayers.
\end{abstract}

INDEX TERMS: Isolation, cultivation, immunofluorescence, lamellar keratinocytes, equine hoof, cell migration, culture technology, skin, tissue engineering.

RESUMO.- [Isolamento, cultivo e caracterização por imunofluorescência de queratinócitos lamelares de casco equino utilizando explantes.] É notória a importância do casco na saúde dos equinos, mas o conhecimento em nível

\footnotetext{
${ }^{1}$ Received on September 10, 2018.

Accepted for publication on November 5, 2018.

2 Departamento de Cirurgia e Anestesiologia Veterinária, Faculdade de Medicina Veterinária e Zootecnia (FMVZ), Universidade Estadual Paulista “Julio de Mesquita Filho" (Unesp), Distrito de Rubião Junior s/n, Botucatu, SP 18618-681, Brazil. *Corresponding author: ana.liz@unesp.br

${ }^{3}$ Departamento de Clínicas Veterinárias, Serviço de Patologia Veterinária, Faculdade de Medicina Veterinária e Zootecnia (FMVZ), Universidade Estadual Paulista "Julio de Mesquita Filho" (Unesp), Distrito de Rubião Junior s/n, Botucatu, SP 18618-681.

${ }^{4}$ Departamento de Urologia (Divisão do Hemocentro), Faculdade de Medicina, Universidade Estadual Paulista “Julio de Mesquita Filho" (Unesp), Distrito de Rubião Junior s/n, Botucatu, SP 18618-681.
}

celular é pouco entendido. Estudos envolvendo o cultivo de queratinócitos equinos são escassos. Sabe-se que o desenvolvimento de cultivos de queratinócitos in vitro é uma condição para estudos sobre a biologia molecular, crescimento e diferenciação celular. Alguns métodos já estão estabelecidos, como para cultivo de queratinócitos de pele, mas poucas metodologias são encontradas para queratinócitos lamelares. 0 objetivo desse estudo foi padronizar o cultivo de queratinócitos provenientes de casco equino visando futuramente associar ao estudo da medicina regenerativa para assim estabelecer um modelo experimental in vitro e indicar o uso criterioso de terapias regenerativas para a laminite equina. Desta forma, o cultivo em monocamada e a caracterização de queratinócitos lamelares foram realizados. Para isso, o método de cultura primária utilizado foi através de explantes obtidos de três regiões do casco (dorso-medial, 
dorsal e dorso-lateral). As células foram caracterizadas para os marcadores anti pan-cytokeratin (AE1/AE3), vimentin (V9), p63 (4A4) e Ki-67 (MIB-1) nos cultivos e nos explantes. As células foram cultivadas até terceira passagem, tendo marcação positiva para pan-CK, p63 e Ki-67 e fraca marcação para vimentina. Já as lâminas epidermais não tiveram marcação de vimentin e Ki-67, porém marcaram acentuadamente para pan-CK e p63. Este estudo demonstrou a exiquibilidade do uso de explantes lamelares do casco de equinos, como forma de isolamento de queratinócitos em cultivos primários, bem como caracterizou a habilidade de proliferação desses queratinócitos em monocamada.

TERMOS DE INDEXAÇÃO: Isolamento, cultivo, imunofluorescência, queratinócitos lamelares, casco equino migração celular, tecnologia de cultivo, engenharia tecidual.

\section{INTRODUCTION}

Several studies have sought to elucidate and characterize healthy tissues of epithelial origin, such as the skin, the eyes, and the hoof, so that they can identify the mechanisms of disease development in these tissues (Parsa et al. 1999, Carter et al. 2010, 2011, Shimabukuro et al. 2014, Linardi et al. 2015). The difficulty in healing or repairing keratinized tissues in horses has led to in vitro investigations mainly on skin and hoof injuries, particularly laminitis. Such studies focus both on the behavior and on the expression of hoof cell protein patterns (Ekcfalck et al. 1990, Wunn et al. 1999, Dahm et al. 2002, Visser \& Pollitt 2010, Pawlak et al. 2014, Sharma et al. 2016).

The cultivation of equine keratinocytes has been researched for decades, and the studies are divided either into the distinct objectives, such as how to obtain the keratinocytes (methods of tissue collection) or by the diverse ways of isolation, culture media and expression of cytokeratins (Ekcfalck et al. 1990, Wunn et al. 1999, Dahm et al. 2002, Visser \& Pollitt 2010, Sharma et al. 2016). An in vitro analysis of the keratinocytes culture of the equine hoof performed by Dahm et al. (2002) demonstrated that these cells have cuboid/oval morphological characteristics.

For the characterization of the keratinocyte culture, antibodies are used to recognize the cytokeratins of these cells of epithelial origin, as specific cytokeratins according to the cellular source. For lamellar cells, the anti-cytokeratin type I and II (Pan-Cytokeratin) antibodies serve as markers of lamellar origin (Visser \& Pollitt 2010). To carry out the negative control of these cultures, many researchers use anti-vimentin markers, which is a protein expressed in cells of mesenchymal origin, that is, cells of epithelial origin do not express it (Wunn et al. 1999, Visser \& Pollitt 2010, Sharma et al. 2016).

The expression of Ki-67 together in p63 positive cells is similar to the expression pattern observed in skin and stratified epidermal cultures, where the expression of such proteins is present in cells that are proliferating or have proliferation capacity (Yang et al. 1998, Senoo et al. 2007).

The equine hoof is formed by epidermis in different stages of keratinization subdivided in stratum externum (or hoof wall), stratum medium, and stratum internum. It is in the latter that the primary epidermal laminae (PEL) and secondary epidermal laminae (SEL) are located, where the keratinocytes are attached to the basement membrane (Pollitt 1995). In cases of endotoxemia, the target regions frequently affected are the dermo-epidermal interfaces of the secondary laminae, consequently causing the onset of laminitis in horses (French \& Pollitt 2004, Belknap et al. 2007, Pollitt 2007).

Despite the great importance of the hoof in equine health, knowledge regarding the cells is still little studied (Carter et al. 2011), and the development of in vitro studies for keratinocyte cultures is essential for understanding the cell growth, differentiation, and cellular and molecular biology (Dahm et al. 2002).

The objective of this study was to standardize the equine hoof keratinocyte culture aiming to associate it with the study of regenerative medicine in the future in order to establish an experimental model in vitro and to indicate the wise use of regenerative therapies for equine laminitis.

\section{MATERIALS AND METHODS}

This was a pilot study performed according to the Brazilian Council for Animal Care and approved by the 'Ethics Committee in the Use of Animals' of the Faculdade de Medicina Veterinária e Zootecnia, Universidade Estadual Paulista - Unesp (Protocol number 151/2016).

Laminar tissue collection. Three samples of laminar tissue were collected from a five-year-old Mangalarga stallion that had died with no history or evidence of hoof or regional disease or alteration. The samples were collected one-hour post mortem.

The limb was sawn into the metacarpal middle third region and washed with soap and water to remove dirt. After cleaning, the hooves were subjected to antisepsis, and sterile surgical fields were positioned in the limb portion to the coronary band. The regions collected from each hoof were in the proximal-middle third in the dorsal (D), lateral dorsal (LD), and medial dorsal (MD) faces, all of them approximately two centimeters distal from the coronary band.

The fragments were collected according to Croser \& Pollitt (2006) and Visser \& Pollitt (2011) with modifications. Briefly, the dorsal, medial and lateral sample collection sites were $2 \mathrm{~cm}$ distal to the hairline of the coronet, and the sites were $4 \mathrm{~cm}$ equidistant. Tissue samples were obtained using a $1.5 \mathrm{~cm}$ diameter hole saw (Starret, BRA) and a drill (Bosch, BRA), both sterile. The perforation was irrigated with sterilizing solution in order to avoid heating the sample until reaching approximately $2 \mathrm{~cm}$ deep, according to the perception of the saw touching the dermis. Subsequently, still with the hole saw, the fragments were luxated from the dermis with proximal to distal movements, then removed and packed into conical tubes containing phosphate-buffered saline - PBS (Gibco, USA) for washing. After being washed in PBS three times, the fragments were packed in a carrier containing antibiotic-antimycotic (amphotericin $\mathrm{B}$, penicillin and streptomycin) zwitterionic buffer HEPES (Gibco, USA) and then sent to the laboratory.

Keratinocyte isolation. The keratinocyte isolation using explants was based on the methodologies of Ekfalck et al. (1990) and Sharma et al. (2016). Concisely, the fragments were washed three times using iodopovidine with decreasing $4 \%, 2 \%$, and $1 \%$ dilution, and then washed with $30 \mathrm{~mL}$ PBS. Afterwards, the fragments were packed into falcon-type tubes with HEPES (Gibco, USA) + 0,6\% antibiotic-antimycotic (Gibco, USA) + amikacin (Teuto, BRA), and kept overnight $(18 \mathrm{~h})$ at $4^{\circ} \mathrm{C}$. After this period, the epidermal laminae were separated from the hoof matrix using a scalpel blade $n=24$. Such epidermal laminae were cut, weighed, and distributed in duplicate with equal weights in Petri dishes. 
Keratinocyte culture. A flask containing 500mL calcium free DMEM (Gibco, USA) culture medium was added supplements with 5\% fetal bovine serum (FBS) (Gibco, USA), 10ng/mL epidermal growth factor (EGF) (Gibco, USA), 30 $\mu \mathrm{g} / \mathrm{mL}$ bovine pituitary extract (BPE) (Gibco, USA), 0.4 $\mu \mathrm{g} / \mathrm{mL}$ hydrocortisone (Blau Pharmaceuticals, BRA), $5 \mu \mathrm{g} / \mathrm{mL}$ insulin (Sigma-Aldrich, USA), 0.6mM calcium (HalixIstar, BRA), $1 \%$ antibiotic-antimycotic (Gibco, USA), and $2.2 \mu \mathrm{L}$ amikacin (Teuto, BRA). The primary cultures were carried out in Petri dishes for 10 days in the presence of the 10 explants per dish, incubated in a humidified atmosphere of $5 \%$ carbon dioxide at $37^{\circ} \mathrm{C}$. Every 48-72 hours, the culture medium was replenished, and the cell growth was monitored by using an inverted phase contrast microscope.

The explants were removed on day 10 and the primary cell culture was cultured until approximately $80 \%$ of confluence, when a selective trypsinization was performed with cold Trypsin-EDTA, according to Kisselbach et al. (2009). This procedure allowed the fibroblast detachment and then we trypsinized the remaining attached cells for 10 minutes using $0.25 \%$ Trypsin-EDTA at $37^{\circ} \mathrm{C}$ (Gibco, USA). The cells were then centrifuged at $251 \mathrm{x} g$ for 10 minutes and washed with the media HEPES (Gibco, USA) and FBS (Gibco, USA).

During the subculture, the cells were grown in six well plates (Sarstedt, GER) and incubated in a controlled environment incubator $\left(5 \% \mathrm{CO}_{2}\right.$ at $\left.37^{\circ} \mathrm{C}\right)$, replenishing the culture medium and monitoring cell growth in an inverted phase contrast microscope (Carl Zeiss Company, GER) every 48-72 hours. At the end of the third passage, the cultures were characterized by immunofluorescence.

Cell culture immunofluorescence. The immunofluorescence was used to characterize the markers following the recommendation of Guo \& Jahoda (2009). In short, a cell-culture glass coverslip was inserted into each of the six wells of a plate, and culture medium was added. Each culture was carefully transferred in quadruplicate into each well of the plate, being dripped on top of the respective coverslips, and incubated at $37^{\circ} \mathrm{C}$ and $5 \% \mathrm{CO}_{2}$. After the cell adhesion to the coverslips, cell fixation was performed by adding $1 \mathrm{~mL}$ methanol $\left(\mathrm{CH}_{3} \mathrm{OH}\right)$ to each well, and the samples were incubated at $4^{\circ} \mathrm{C}$ for 30 minutes. Thereafter, cell permeabilization was performed using $0.2 \%$ Tween 20 (DAKO, DK) for $10 \mathrm{~min}$.

The non-specific proteins were blocked using a commercial protein block solution (Spring Bioscience, USA), and were incubated at $27^{\circ} \mathrm{C}$ for 20 minutes. Next, the primary antibodies were incubated overnight at $4^{\circ} \mathrm{C}$. The primary antibodies used were pan-CK AE1/AE3 (sc81714, Santa Cruz Biotechnology, USA) and Vimentin (V9 - sc6260, Santa Cruz Biotechnology, USA), both at 1:300 dilution, in addition to p63 (4A4 - sc8431, Santa Cruz Biotechnology, USA) and Ki-67 (Mib-1-clone - M7240, DAKO, DK), primary antibodies, both at 1:100 dilution. The secondary antibody Alexa Fluor 532 (A11002, Life Technology, CAN) was used at $5 \mu \mathrm{g} / \mathrm{mL}$ concentration and incubated in the dark for 30 minutes at room temperature. After that, diamidino-2-phenylindole, DAPI (Sigma-Aldrich, USA), was added at 1:1000 dilution to each coverslip. The samples were analyzed by confocal TCS SP5 laser scanning microscope (Leica Microsystems, GER). After the immunofluorescence labeling analysis, the positive cells were counted in each sample in a $15 \mathrm{~mm}$-diameter area (coverslip area), with the mean of the count being defined as a percentage of the positive cells (positive cells/total cells).

Lamellar explant immunofluorescence. Lamellar explant fragments were fixed in $10 \%$ buffered formalin solution and embedded in paraffin. The tissue sections with $4 \mu \mathrm{m}$ were prepared in a manual microtome (Leica Microsystems, GER) and were placed on immunohistochemistry slides (Starfrost, Knittel, Germany). The antigen retrieval was performed using a citrate buffer solution in a pressure cooker (DakoCytomation, Carpinteria, CA, USA). Consequently, the endogenous peroxidase blocking was performed with $8 \%$ peroxidase solution diluted in methanol for 10 minutes. The non-specific proteins were blocked using a commercial protein block solution (Spring Bioscience, USA) and then incubated at $27^{\circ} \mathrm{C}$ for 20 minutes. Afterwards, the primary antibodies were incubated overnight at $4^{\circ} \mathrm{C}$. The antibodies anti-cytokeratin, anti-vimentin, anti-p63 (4A4, Santa Cruz Biotechnology, USA), and anti-Ki-67 (Mib-1-clone, DAKO, DK) were diluted at 1:300, 1:300, 1:50, and 1:50, respectively (Robertson et al. 2008). The secondary antibody Alexa Fluor 532 was used at $5 \mu \mathrm{g} / \mathrm{mL}$ concentration and incubated in the dark for 30 minutes at room temperature. The samples were analyzed by confocal TCS SP5 laser scanning microscope (Leica Microsystems, GER).

\section{Keratinocyte culture}

\section{RESULTS}

After the explants were plated for three days, cells with ovoid/cuboidal morphology and variable size $(20 \mu \mathrm{m}$ length and $15 \mu \mathrm{m}$ width, approximately) appeared under the explants adhered to the plate (Fig.1A). Within this time, some explants had some adherence to the plate, which later demonstrated low cellularity. In some of these explants, the surrounding cells were observed to come out from under the explants more slowly than others in the first days of culture. Seven days after plating, cells in proliferation with ovoid/cuboidal morphology and cells adhered were observed. At day 10 , the explants were removed from the culture plates, which were maintained until reaching $80 \%$ confluence to make the passage.

Cells with fibroblastic characteristics were not observed in the cultures, neither when in subculture. A grouping of cells with stratified formation (Fig.1B) was observed, probably by an adaptation to the in vitro environment, since they are cells originating from the keratinized stratified epithelium. There was no difference in cell migration and proliferation among the collected regions (D, LD and MD).

\section{Monolayer culture immunofluorescence}

The pan-CK antibody had strong staining in the subculture cells of all three cultures (3/3). This positivity confirms that the cultured cells had epithelial origin (Fig.2A). The anti-vimentin antibody was positive in few cells and most of the cell population had no vimentin staining (Fig.2C). The basal cell marker p63 was positive in more than $90 \%$ of cells (Fig.2E). It was possible to identify the proliferation potential of cell cultures by Ki-67 (Fig.2G). It was justified by the explant immunofluorescence, as the cells coming out from under the explants and the axial cells were absent and negative for Ki-67, which maybe demonstrated that the cells might have migrated from the explant.

\section{Explants immunofluorescence}

The explant immunofluorescence analysis after the removal of the primary culture had a similar immunohistochemical pattern to the monolayer cultures. It was possible to identify positive pan-CK expression (Fig.3A) and negative vimentin expression in epithelial cells. Stromal cells of secondary dermal laminae were positive for vimentin (Fig.3B).

Interestingly, the p63 immunostaining of the explants revealed positive cells adjacent to the basement membrane of the SEL (Fig.3C). Thus, p63 positive cells were limited to 

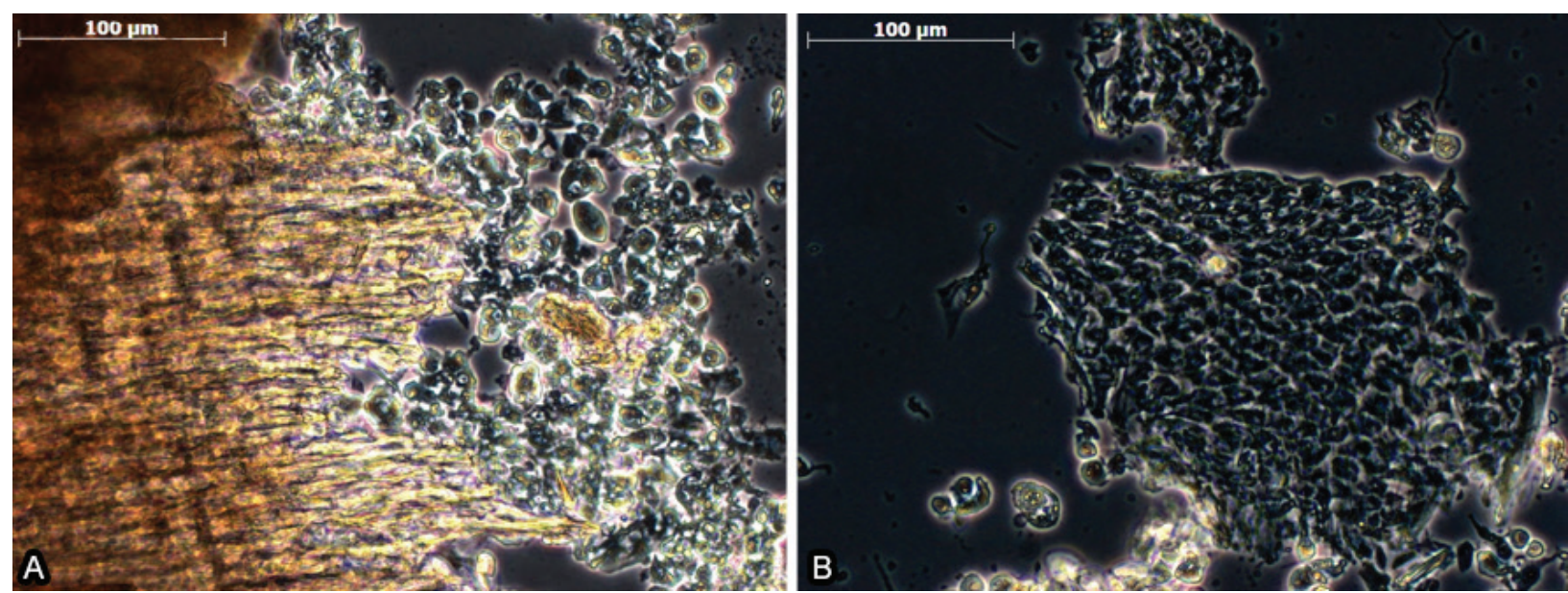

Fig.1. Inverted microscopy with phase contrast of primary cultures in monolayer. (A) Cells migrating to the culture plate and appearing beneath the explants. (B) Cell groupings in stratified epithelial formation typical of keratinocytes due to their epidermal origin. Ovoid cells are also observed. Obj.20x.

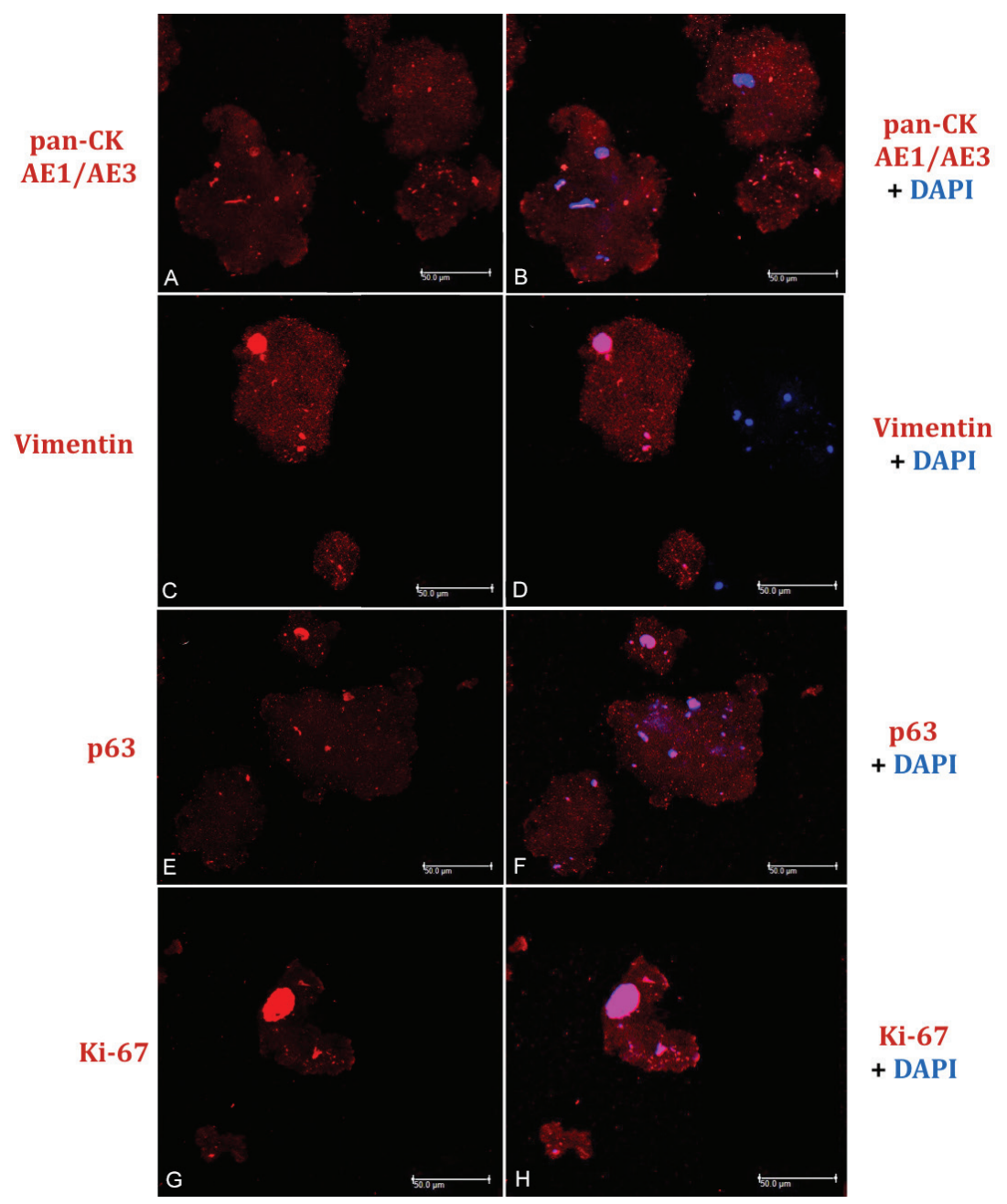

Fig.2. Keratinocyte culture immunofluorescence in monolayer. Red fluorophore labeling due to secondary antibody (Alexa Fluor 532) and blue due to nucleus labeling by DAPI. (A) Positivity for pan-CK due to cytoplasmic labeling in red. (B) Merged labeling image, in blue DAPI and red pan-CK. (C) Cytoplasmic labeling in red positive for vimentin. (D) Merged labeling image, in pink Alexa Fluor $532+$ DAPI labeling cell nucleus, and negative labeling for vimentin in blue dots was also observed. (E) Positivity for p63. (F) Merged image, in pink Alexa Fluor 532 + DAPI labeling cell nucleus. (G) Ki-67 positivity evident by the red color in nucleus. (H) Merged image, the pink nucleus due to the sum of the secondary red for the Ki-67 nuclear antibody and the blue of DAPI, which marks the cellular nucleus. Some punctual markings can be observed in all images, yet with no relevance. Laser confocal microscopy, obj.40x. 


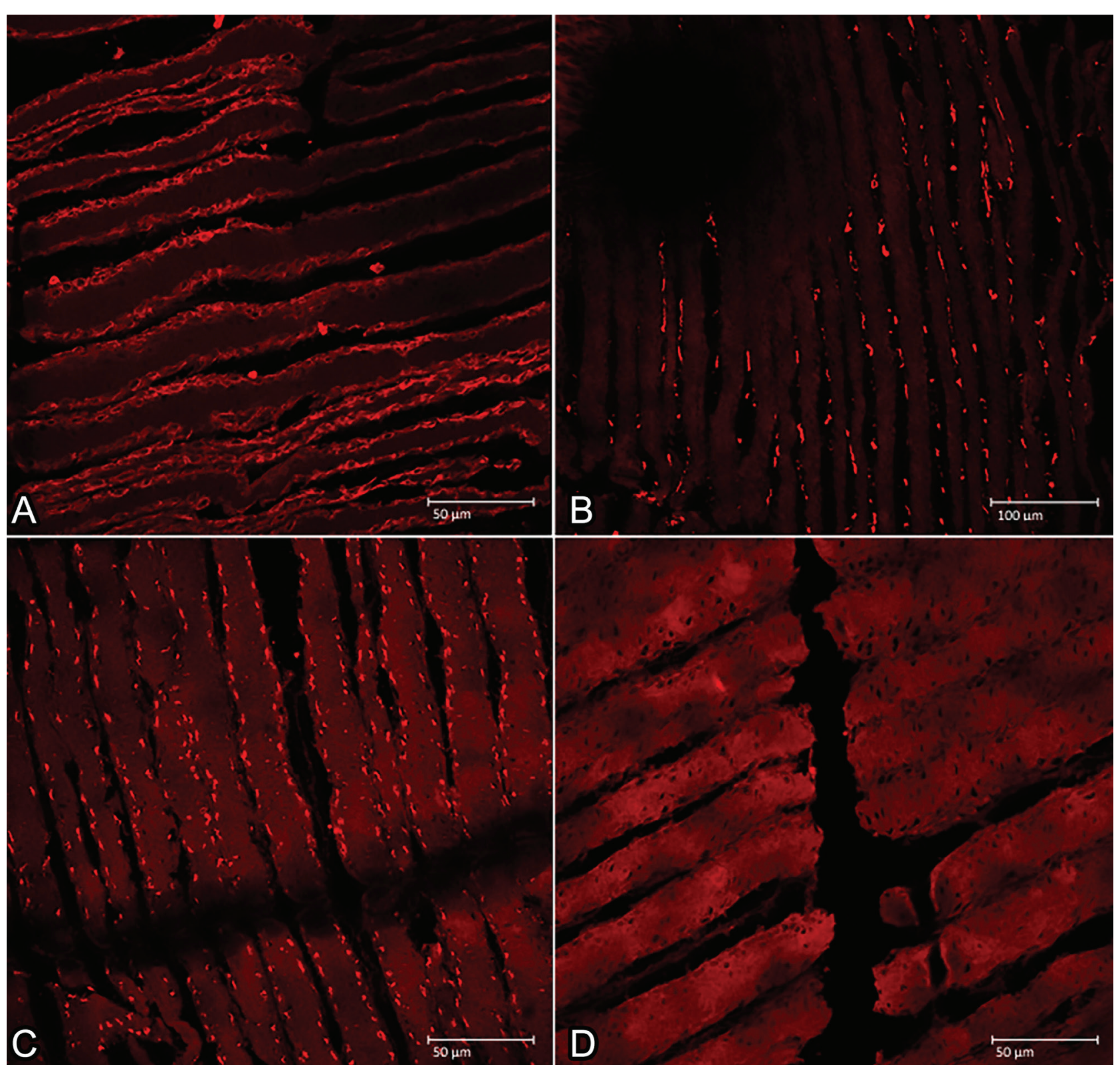

Fig.3. Immunofluorescence of the explants (epidermal laminae) after removal of the primary culture. (A) Cytoplasmic deep red pan-CK labeling in cells of the basal layer on the secondary laminae. Laser confocal microscopy, obj.40x. (B) Vimentin labeling was limited to the secondary dermal laminae region. Laser confocal microscopy, obj.20x. (C) Nuclear labeling of p63 in the cells present in the basal layer of the secondary laminae. Laser confocal microscopy, obj.40x. (D) Negative Ki-67 labeling where the cell nuclei appear dark. Laser confocal microscopy, obj.40x.

the germ cell layer, adjacent to the basal membrane of the SEL. The positive cells remained in these explants and did not migrate to the culture plate. Only the axial keratinocytes in the SEL of these explants might have migrated.

Ki-67 positive cells were identified in all analyzed explants (3/3) (Fig.3D). The positive cells were restricted to the basal membrane of the SEL.

\section{DISCUSSION}

From the standardization of equine hoof epidermal cell culture, an important step in the development of new therapies for equine laminitis can be taken by creating an experimental model in vitro, thereby limiting the use and induction of such disease in animals for its study. In ours, the culture and characterization of lamellar keratinocytes of a healthy horse using explants as primary culture was successful. This method was based on previous research (Ekfalck et al. 1990, Sharma et al. 2016). The concentrations of the culture medium and supplements used were crucial to perform the lamellar keratinocyte culture in monolayer, especially the calcium concentration, which can influence the cellular proliferation and differentiation (Hennings et al. 1980). According to Dahm et al. (2002) and Visser \& Pollitt (2010), the ideal culture medium for keratinocytes of lamellar origin is using DMEM medium with low calcium concentration $(0.6 \mathrm{mM})$. 
Using 5\% FBS since the primary culture was important, and it corroborates with our results, since the FBS supplementation around $2 \%$ can lead to cellular stress. Thus, $5 \%$ concentration was shown to be ideal for the keratinocytes culture by using explants (Sharma et al. 2016). Fibroblasts commonly appear in primary cultures and are separated from the plate along the trypsinizations or when specific enzymes are used to separate only this type of cell (Visser \& Pollitt 2010). The absence of fibroblast cells was confirmed by the positive result in pan-CK and p63 expression assays, since fibroblasts do not express pan-CK or p63 (Lupatov et al. 2015). The absence of fibroblasts in the cultures may have occurred due to the caution in separating the epidermal laminae from the dermal tissue of the samples collected. Visser \& Pollitt (2010) reported that such care is essential, so that there is no contamination by fibroblasts in the keratinocyte cultures. We did not perform flow cytometry to verify the cell immunophenotype due to the low number of cells isolated from each culture. Instead, we performed immunofluorescence to confirm the origin of each cell type that grew in culture conditions, according to Guo \& Jahoda (2009). Even though the referred study was not performed with equine epithelial tissue, we found similar results, which prove that most of our cells had keratinocyte characteristics.

There was no variation on the cellular migration rate among the three different sites of sampling. This could be explained by the fact that all the sites were situated mainly in the dorsal aspect of the hoof wall. The nomenclature "LD" and "MD" was given comparing where they are to the central site of sampling, located in the central axis of the limb. Moreover, all the samples were obtained taking the same distance of the coronary region.

The keratinocyte culture characterization demonstrated the cell phenotype, indicating the origin and differentiation stage of these cells. The epithelial origin of cultured cells was confirmed by pan-cytokeratin expression, which recognized acidic and basic cytokeratins, types I and II, respectively. Cytokeratins are intermediate filaments of epithelial cells (Wilkinson et al. 1989) used to recognize cytokeratins from the hoof wall (Wattle 1998, Visser \& Pollitt 2010). The cell morphology associated with the expression of pan-CK suggested these cells were keratinocytes. We also performed a fibroblast selective detachment using cold Trypsin-EDTA.

Vimentin is known to target cells or tissues of mesenchymal origin, like fibroblasts present in the dermis. Equine skin keratinocytes do not express vimentin (Dahm et al. 2002, Sharma et al. 2016). However, cells in culture condition can be submitted to different transcriptional modification, and vimentin expression by epithelial cells in culture conditions is widely reported (Coggi et al. 1989, Richard et al. 1990, Mahabal et al. 2016). Other studies evaluating lamellar keratinocytes have demonstrated that they can express vimentin when in culture (Wunn et al. 1999, Visser \& Pollitt 2010), and such positive expression for vimentin may be an adaptation to the in vitro environment (Coggi et al. 1989, Richard et al. 1990). The positive result for vimentin in few cells can justify the adaptive condition of cells to the in vitro environment. Another result confirming the theory found in the literature was that the explants did not express vimentin, which is restricted to the secondary dermal laminae region.

The protein p63 in association with the other markers give evidence that the cells are keratinocytes. The p63 is a protein encoded by the TP63 gene and represents a nuclear specific marker for keratinocyte proliferation and differentiation, showing a decrease in its expression, mainly in prolonged cultures (Truong \& Khavari 2007). The cytokeratin+/ vimentin-/p63+ phenotype indicates the epidermal origin of the cells in our experiment, as this phenotype can be found in keratinocytes.

The evaluation of proliferation potential and maturation stage in which the keratinocytes are found, both in vitro and in vivo, is important so as to know how much the culture is still able to proliferate. The expression of p63 and Ki-67 was found in the cultured cells maintained until the third passage. It is also known that p63 is an epidermal stem cell (ESC) regulatory molecule, an intranuclear protein that is an expression marker related with the potential of cell proliferation (Parsa et al. 1999, Carter et al. 2011). Linardi et al. (2015) showed that in order to characterize and differentiate the presence of epidermal stem cells from the skin, coronary, and lamellar regions of equine hooves, there must be a combination of molecule p63 expression together with p63 phosphorylated molecule (pp63), which is a marker of the transition from ESC to transit-amplifying cell. On the other hand, Ki-67 is a protein present in the nucleolus of keratinocytes that are active in the cell cycle (Scholzen \& Gerdes 2000), so its presence is a prerequisite for cultures performed for an extended period (Dahm et al. 2002).

The expression of Ki-67 together with p63 positive cells is similar to the pattern of expression observed in the skin and stratified epidermal cultures. The expression of p63 is present only in proliferating cells or those that have this ability (Yang et al. 1998, Senoo et al. 2007), which suggests what has been described by Blanpain \& Fuchs (2009). They reported that the p63 positive cells in the coronary of the hoof, the periople region, continuously provide epithelium to generate hoof wall in rapid growth, while p63 positive cells in the lamellar function have action in the homeostasis maintenance and tissue repair, like their function in the skin.

However, Ki-67 labeling was not observed in the epidermal slides used as explants, only a poor labeling of p63, possibly due to the stage and stress to which those cells that did not migrate to the culture plate were subjected, as the labeling of these two molecules denote keratinocyte proliferative potential.

\section{CONCLUSIONS}

This study demonstrated the viability of lamellar explants of equine hooves as a form of keratinocyte isolation in primary culture, as well as characterized the proliferation ability of these keratinocytes in monolayers.

The results point to the need to implement the protocol used with techniques and methodologies that promote greater migration of explant cells to the culture environment. This implementation will be a tool as an experimental model for the evaluation of therapeutic studies that can elucidate cell behavior and evaluate the potential use of regenerative medicine as a treatment for equine laminitis.

\footnotetext{
Acknowledgments.- To the Laboratory of Cellular Engineering - Blood Center of the Medicine School, Unesp Botucatu - coordinated by Prof. Elenice Deffune; To the Laboratory of Immunohistochemistry coordinated by Prof. Renée Laufer Amorim; To the Electronic Microscopy Center of Biology Institute of Unesp Botucatu; and to the technician Shelly F. Carvalho; to the Coordination for the Improvement of Higher Education Personnel (CAPES) for the fellowship.
} 
Conflict of interest statement.- The authors declare that there is no conflict of interest.

\section{REFERENCES}

Belknap J.K., Giguère S., Pettigrew A., Cochran A.M., Van Eps A.W. \& Pollitt C.C. 2007. Lamellar pro-inflammatory cytokine expression patterns in laminitis at the developmental stage and at the onset of lameness: innate vs. adaptive immune response. Equine Vet. J. 39(1):42-47. <PMid:17228594>

Blanpain C. \& Fuchs E. 2009. Epidermal homeostasis: a balancing act of stem cells in the skin. Nat. Rev. Mol. Cell Biol. 10(3):207-217. <http://dx.doi. org/10.1038/nrm2636><PMid:19209183>

Carter R.A., Shekk V., de Laat M.A., Pollitt C.C. \& Galantino-Homer H.L. 2010. Novel keratins identified by quantitative proteomic analysis as the major cytoskeletal proteins of equine (Equus caballus) hoof lamellar tissue. J. Anim.Sci. 88(12):3843-3855. <http://dx.doi.org/10.2527/jas.2010-2964> $<$ PMid:20622188>

Carter R.A., Engiles J.B., Megee S.O., Senoo M. \& Galantino-Homer H.L. 2011. Decreased expression of p63, a regulator of epidermal stem cells, in the chronic laminitic equine hoof. Equine Vet. J. 43(5):543-551. <http://dx.doi. org/10.1111/j.2042-3306.2010.00325.x> <PMid:21496086>

Coggi G., Dell'Orto P., Braidotti P., Coggi A. \& Viale G. 1989. Coexpression of intermediate filaments in normal and neoplasia human tissues: a reappraisal. Ultrastruct. Pathol. 13(5/6):501-514. <http://dx.doi. org/10.3109/01913128909074533><PMid:2678645>

Croser E. \& Pollitt C.C. 2006. Acute laminitis: descriptive evaluation of serial hoof biopsies. 52nd Annual Convention of the American Association of Equine Practitioners, San Antonio, Texas, p.542-546. (Abstract)

Dahm A.M., de Bruin A., Linat A., von Tscharner C., Wyder M. \& Suter M.M. 2002. Cultivation and characterization of primary and subcultured equine keratinocytes. Equine Vet. J. 34(2):114-120. <http://dx.doi. org/10.2746/042516402776767187> <PMid:11902754>

Ekfalck A., Rodriguez-Martinez H. \& Obel N. 1990. Cultivation of tissue from the matrix of stratum medium of the equine and bovine hoof walls. Am. J. Vet. Res. 51(11):1852-1856. <PMid:2240811>

French K.R. \& Pollitt C.C. 2004. Equine laminitis: loss of hemidesmosomes in hoof secondary epidermal lamellae correlates to dose in an oligofructose induction model: an ultrastructural study. Equine Vet. J. 36(3):230-235. <http://dx.doi.org/10.2746/0425164044877125> <PMid:15147130>

Guo A. \& Jahoda C.A. 2009. An improved method of human keratinocyte culture from skin explants: cell expansion is linked to markers of activated progenitor cells. Exp. Dermatol. 18(8):720-726.

Hennings H., Michael D., Cheng C., Steinert P., Holbrook K. \& Yuspa S.H. 1980. Calcium regulation of growth and differentiation of mouse epidermal cells in culture. Cell 19(1):245-254. <http://dx.doi.org/10.1016/00928674(80)90406-7> <PMid:6153576>

Kisselbach L., Merges M., Bossie A. \& Boyd A. 2009. CD90 Expression on human primary cells and elimination of contaminating fibroblasts from cell cultures. Cytotechnology 59(1):31-44. <http://dx.doi.org/10.1007/ s10616-009-9190-3> <PMid:19296231>

Linardi R.L., Megee S.O., Mainardi S.R., Senoo M. \& Galantino-Homer H.L 2015. Expression and localization of epithelial stem cell and differentiation markers in equine skin, eye and hoof. Vet. Dermatol. 26(4):213-247. <http:// dx.doi.org/10.1111/vde.12214><PMid:25963063>

Lupatov A.Y., Vdovin A.S., Vakhrushev I.V., Poltavtseva R.A. \& Yarygin K.N. 2015. Comparative analysis of the expression of surface markers on fibroblasts and fibroblast-like cells isolated from different human tissues. Bull. Exp. Biol. Med. 158(4):537-543. <http://dx.doi.org/10.1007/s10517-0152803-2> <PMid:25708341>

Mahabal S., Konala V.B., Mamidi M.K., Kanafi M.M., Mishra S., Shankar K., Pal R. \& Bhonde R. 2016. Sequential cultivation of human epidermal keratinocytes and dermal mesenchymal like stromal cells in vitro. Cytotechnology
68(4):1009-1018. <http://dx.doi.org/10.1007/s10616-015-9857-x> <PMid:25698160>

Parsa R., Yang A., Mckeon F. \& Green H. 1999. Association of p63 with proliferative potential in normal and neoplastic human keratinocytes. J. Invest. Dermatol. 113(6):1099-1105. <http://dx.doi.org/10.1046/j.1523-1747.1999.00780. x><PMid:10594758>

Pawlak E.A., Geor R.J., Watts M.R., Black S.J., Johnson P.J. \& Belknap J.K. 2014. Regulation of hypoxia-inducible factor-1alpha and related genes in equine digital lamellae and in cultured keratinocytes. Equine Vet. J. 46(2):203-209. <http://dx.doi.org/10.1111/evj.12092> <PMid:23663159>

Pollitt C.C. 1995. Color Atlas of The Horses's Foot. Mosby-Wolfe, London, p.15-39.

Pollitt C.C. 2007. Laminitis Pathophysiology, p.313-319 In: Floyd A.E. \& Mansmann R.E. (Eds), Equine Podiatry. Saunders Elsevier, Saint Louis. <http://dx.doi.org/10.1016/B978-072160383-4.50019-0>

Richard M.H., Viac J., Reano A., Gaucherand M. \& Thivolet J. 1990. Vimentin expression in normal human keratinocytes grown in serum-free defined MCDB 153 medium. Arch. Dermatol. Res. 282(8):512-515.<http://dx.doi. org/10.1007/BF00371945><PMid:2082832>

Robertson D., Savage K., Reis-Filho J.S. \& Isacke C.M. 2008. Multiple immunofluorescence labelling of formalin-fixed paraffin-embedded (FFPE) tissue. BMC Cell Biol. 9(1):13. <http://dx.doi.org/10.1186/1471-2121-913> <PMid:18366689>

Scholzen T. \& Gerdes J. 2000. The Ki-67 protein: from the known and the unknown. J. Cell Physiol. 182(3):311-322. <http://dx.doi.org/10.1002/ (SICI)1097-4652(200003)182:3<311::AID-JCP1>3.0.C0;2-9><PMid:10653597>

Senoo M., Pinto F., Crum C.P. \& Mckeon F. 2007. p63 is essential for the proliferative potential of stem cells in stratified epithelia. Cell 129(3):523536. <http://dx.doi.org/10.1016/j.cell.2007.02.045><PMid:17482546>

Sharma R., Barakzai S.Z., Taylor S.E. \& Donadeu F.X. 2016. Epidermal-like architecture obtained from equine keratinocytes in three-dimensional cultures. J. Tissue Eng. Regen. Med. 10(8):627-636. <http://dx.doi. org/10.1002/term.1788> <PMid:23897780>

Shimabukuro J., Yamaoka A., Murata K., Kotani E., Hirano T., Nakajima Y., Matsumoto G. \& Mori H. 2014. 3D co-cultures of keratinocytes and melanocytes and cytoprotective effects on keratinocytes against reactive oxygen species by insect virus-derived protein microcrystals. Mater. Sci. Eng. C, Mater. Biol. Appl. 42:64-69. <http://dx.doi.org/10.1016/j. msec.2014.05.013><PMid:25063093>

Truong A.B. \& Khavari P.A. 2007. Control of keratinocyte proliferation and differentiation by p63. Cell Cycle, Georgetown 6(3):295-299. <http:// dx.doi.org/10.4161/cc.6.3.3753> <PMid:17264679>

Visser M.B. \& Pollitt C.C. 2010. Characterization of extracellular matrix macromolecules in primary cultures of equine keratinocytes. BMC Vet. Res. 6(1):16. <http://dx.doi.org/10.1186/1746-6148-6-16><PMid:20230631>

Visser M.B. \& Pollitt C.C. 2011. The time line of lamellar basement membrane changes during equine laminitis development. Equine Vet. J. 43(4):471-477. <http://dx.doi.org/10.1111/j.2042-3306.2010.00292.x><PMid:21496071>

Wattle 0. 1998. Cytokeratins of the equine hoof wall, chestnut and skin: bio- and immunohisto-chemistry. Equine Vet. J. Suppl. 26(26):66-80. <PMid:9932096>

Wilkinson J.E., Lee C.S., Lillie J.H., Suter M.M. \& Lewis R.M. 1989. Ultrastructure of cultured canine oral keratinocytes. Am. J. Vet. Res. 50(7):1161-1165. <PMid:2476052>

Wunn D., Wardrop K.J., Meyers K., Kramer J. \& Ragle C. 1999. Culture and characterization of equine terminal arch endothelial cells and hoof keratinocytes. Am. J. Vet. Res. 60(1):128-132. <PMid:9918161>

Yang A., Kaghad M., Wang Y., Gillett E., Fleming M.D., Dötsch V., Andrews N.C., Caput O. \& Mckeon F. 1998. p63, a p53 homolog at 3q27-29, encodes multiple products with transactivating, death-inducing, and dominantnegative activities. Mol. Cell 2(3):305-316. <http://dx.doi.org/10.1016/ S1097-2765(00)80275-0> <PMid:9774969> 